OPEN ACCESS

Edited by:

Andrea M. Feldpausch-Parker,

SUNY College of Environmental

Science and Forestry, United States

Reviewed by:

Julie MacArthur,

University of Auckland, New Zealand

Henner Busch,

Lund University, Sweden

*Correspondence:

Jennie C. Stephens

j.stephens@northeastern.edu

Specialty section:

This article was submitted to Science and Environmental

Communication,

a section of the journal

Frontiers in Communication

Received: 16 November 2017

Accepted: 05 September 2018

Published: 03 October 2018

Citation:

Stephens JC, Burke MJ, Gibian B, Jordi $E$ and Watts $R$ (2018)

Operationalizing Energy Democracy:

Challenges and Opportunities in

Vermont's Renewable Energy

Transformation. Front. Commun. 3:43.

doi: $10.3389 / f c o m m .2018 .00043$

\section{Operationalizing Energy Democracy: Challenges and Opportunities in Vermont's Renewable Energy Transformation}

\author{
Jennie C. Stephens ${ }^{1 *}$, Matthew J. Burke ${ }^{2}$, Brock Gibian ${ }^{3}$, Elie Jordi ${ }^{3}$ and Richard Watts ${ }^{4}$ \\ ${ }^{1}$ School of Public Policy and Urban Affairs, Northeastern University, Boston, MA, United States, ${ }^{2}$ Department of Natural \\ Resource Sciences, McGill University, Sainte-Anne-de-Bellevue, QC, Canada, ${ }^{3}$ Rubenstein School of Environment and \\ Natural Resources, University of Vermont, Burlington, VT, United States, ${ }^{4}$ Community Development and Applied Economics, \\ University of Vermont, Burlington, VT, United States
}

As the social movement promoting "energy democracy" expands, analysis of how the principles of energy democracy are being operationalized is increasingly valuable. The state of Vermont provides a unique case of a United States jurisdiction intentionally promoting multiple ideals of energy democracy as the state commits to transitioning toward renewable energy. This research explores how energy democracy principles are being operationalized in the state of Vermont. Collaboration among stakeholders state-wide has resulted in a variety of social innovations that advance energy democracy goals, yet there are limited examples of community ownership and there is strong community opposition to some renewable projects. A diverse set of stakeholders in this small state has developed and promoted the adoption of a comprehensive energy plan with a goal of achieving 90\% renewables in all sectors (electricity, heating, and transportation) by 2050. These stakeholders are aligned toward achieving this goal, and a socially innovative, networked effort seeks to establish a creative and inclusive environment for individuals, communities and organizations to benefit in the renewable energy transformation. A collaborative culture has created a protected environment where social innovation and experimentation are supported and encouraged, yet tension and community opposition surrounds some wind and solar projects. Reviewing social innovations in Vermont highlights challenges and opportunities of operationalizing energy democracy and emphasizes the importance of local community and public ownership to distribute the economic and political power associated with renewable energy.

\section{Keywords: energy democracy, renewable energy, Vermont, energy innovation, social innovation}

\section{INTRODUCTION}

The transition away from fossil fuels toward more renewable-based energy systems is underway taking shape differently in different communities, states, and countries throughout the world (Brown et al., 2015; Princen et al., 2015). Although there is a common tendency to view the renewable transition in technical and economic terms, current energy system changes involve much more than a technical substitution from fossil fuels to renewable electricity generation; this transition also involves social, institutional, and cultural innovations (Stephens et al., 2015). 
Energy democracy is an emergent social movement focused on advancing renewable energy transitions by resisting the dominant energy agenda while reclaiming and democratically restructuring energy regimes (Burke and Stephens, 2017; Van Veelen and Van Der Horst, 2018). By integrating technological change with the potential for socioeconomic and political change, the movement links social justice and equity with all kinds of innovation in energy (both social and technical innovations). The energy democracy movement seeks to create opportunities for destabilizing power relations (Angel, 2016a), reversing histories of dispossession, marginalization (Duda, 2015; Farrell, 2016) and social and environmental injustices (EDANY, 2016), and replacing monopolized fossil fuel energy systems with democratic and renewable structures (Kunze, 2014). Above all, energy democracy offers a set of visionary organizing principles that provide guidance for democratically restructuring the energy and electricity sectors through the processes of shifting from fossil fuel-based systems to renewable energy systems (Sweeney, 2014; Angel, 2016b).

Given the culturally and politically embedded nature of fossilfuel based energy systems, energy democracy principles threaten the status quo so resistance is strong and operationalizing energy democracy remains challenging. Despite the powerful intensity of this resistance, facilitating the renewable energy transition is becoming a political priority in jurisdictions throughout the world (Busch and Mccormick, 2014; Geels et al., 2017; Stokes and Breetz, 2018). The German "Energiewende" is among the most ambitious and comprehensive national-level energy policies promoting the renewable energy transition (Maatsch, 2014), and its grassroots community ownership approach to the transition provides examples of energy democracy (Morris and Jungjohann, 2016). Although the United States does not have a similar comprehensive national-level energy transition policy (Stokes and Breetz, 2018), at the sub-national level several states have made policy commitments to the renewable energy transition and are intentionally attempting to support principles of energy democracy.

As the energy democracy movement expands and multiple different narratives emerge to describe what the phrase means (Burke, 2018), exploring the operationalization of energy democracy, i.e., the tangible innovative initiatives that are developing to implement its principles, provides insights on the evolution of both the concept and the movement. Multiple meanings and narratives of what energy democracy is or could be co-exist and are evolving differently among different organizations and communities (Burke, 2018). A recent review of policies that align with energy democracy principles highlights the limited empirical research on the implementation and practice of operationalizing energy democracy in different jurisdictions (Burke and Stephens, 2017). A recent mapping of the usage of the term "energy democracy" outlines the concept as both an analytical and decision-making tool, operationalized along three dimensions: popular sovereignty, participatory governance, and civic ownership (Szulecki, 2018). Empirical research exploring how energy democracy is being operationalized in different jurisdictions is limited, yet valuable.
With a focus on the state of Vermont, this research asks how energy democracy principles are being operationalized, and what are the challenges and opportunities of operationalizing energy democracy. Vermont provides a unique case of a United States jurisdiction intentionally promoting multiple ideals of energy democracy as the state commits to transitioning toward renewable energy. Vermont provides a particularly interesting case because of their progressive and participatory approach to governance and their adoption of a comprehensive energy plan that includes a goal of achieving $90 \%$ renewables in all sectors (electricity, heating/cooling, and transportation) by 2050 (Vermont Public Service Department, 2016). While a few other states have been striving for similar goals, Vermont was a first-mover and leader in embracing such an ambitious goal that acknowledges transformation. Although, the Vermont Comprehensive Energy Plan is not a legal statute, it serves to articulate expectations that provide protective and supportive space for energy innovations; both technological and social innovations some of which attempt to redistribute economic and political power (Smith and Raven, 2012; Vermont Public Service Department, 2016).

Review and analysis of energy innovations in the state of Vermont provides valuable insights on operationalizing energy democracy principles and policies as part of the renewable energy transition (Levine, 2016). Vermont, one of the smallest states in the United States with a total population of only 626,560 people, has integrated social and technical innovation in its efforts to move toward the climate-justified goal of achieving 90\% renewable energy by 2050 (Clegg, 2014; Reed, 2015). This goal includes electricity, heating/cooling in buildings, and transportation (Vermont Public Service Department, 2016), and stakeholders throughout the state recognize the social change potential involved in achieving this goal (EAN, 2016). To facilitate this transition, progressive cross-sectoral coalitions of Vermonters are working toward various social, political, and institutional innovations that can be viewed as examples of operationalizing energy democracy goals. Some of these innovations include a new model for electric utilities (Parker and Huessy, 2014), sophisticated energy efficiency programs that serve low income communities, and local and regional energy planning.

Although the term "energy democracy" is not widely used within the state of Vermont, multiple social innovations in energy within the state are based on energy democracy principles (Farrell, 2014; Burke and Stephens, 2017). Within the United States, Vermont is a clear leader in renewable energy innovation and operationalizing energy democracy goals. Despite this leadership role in energy innovations, the state has received limited out-of-state and international recognition for the extent and diversity of its energy innovations. An important goal of this paper, therefore, is to showcase to the international community the unique innovative environment in Vermont with respect to energy transitions and energy democracy.

To explore the challenges and opportunities of operationalizing energy democracy, this paper reviews multiple energy innovations in Vermont. The paper will first introduce the concept and emerging social movement of energy democracy, 
review the goals/ideals of the energy democracy movement, and then review and discuss several specific social innovations that can be categorized as operationalizing energy democracy.

\section{THEORETICAL CONTEXT}

The term energy democracy is being used increasingly by grassroots activists in the United States, parts of Europe, and elsewhere (Burke, 2018; Burke and Stephens, 2018; Szulecki, 2018). Energy democracy is a concept that is used to call for and justify integrations of policies linking social justice and economic equity with renewable energy transitions (Burke and Stephens, 2017). Energy democracy is one approach to guiding energy transitions which are increasingly recognized to involve an integrated perspective that includes economic development, technological innovation, and policy changes (Cherp et al., 2018). This empirical review of a set of innovative energy initiatives in Vermont that operationalize energy democracy principles embraces this integration. This focus on initiatives in one small state provides a specific context within which to explore challenges and opportunities of operationalizing energy democracy.

\section{Energy Democracy ${ }^{1}$}

Energy democracy is a novel concept, an emergent social movement, and a decision-making tool that connects energy infrastructural change with the possibilities for deep political, economic, and social change (Szulecki, 2018). The term is used in climate justice, trade unions, academic communities, and political parties, while also recently becoming more mainstream in some regional and national level discourses (Angel, 2016b; Szulecki, 2018).

Energy democracy has been characterized as involving three related but discrete approaches to facilitating renewable energy transformation; energy democracy includes efforts to resist, reclaim, and restructure energy systems (Sweeney, 2012, 2014). Resisting the legacy centralized fossil and nuclear dominated energy systems is key to the energy democracy movement, as is reclaiming energy systems for more distributed economic and political benefits and restructuring energy systems to support the types of democratic relationships necessary for community-based decision-making authority (Hoffman and High-Pippert, 2005; Weinrub and Giancatarino, 2015).

Energy democracy has emerged in the context of an increasing sense of urgency regarding global anthropogenic climate change, although the primary motivation for energy democracy is social justice rather than climate change (Islar and Busch, 2016). Despite a growing recognition of the inherent unsustainability and injustice of fossil fuel civilization (Healy and Barry, 2017), an inability to adequately reduce fossil fuel dependency persists. The issue of and need for shifting away from fossil fuel-dominant systems toward renewable-based energy has therefore become a central

${ }^{1}$ This section providing background on Energy Democracy is adapted from Burke and Stephens (2017). theme for science, politics, and public discourse worldwide (Jacobson and Delucchi, 2011; Markard et al., 2012; Araujo, 2014; Boyer, 2014; Brown et al., 2015; IRENA, 2017). How the decline in fossil fuel reliance plays out is likely to be among the most contested areas of policy and politics over the coming decades (Meadowcroft, 2009; Boyer, 2014; Stirling, 2014; Arent et al., 2017; REN21, 2017).

Energy democracy requires a re-imagining of energy politics (Miller et al., 2013; Burke and Stephens, 2018). The energy democracy movement seeks to create opportunities for destabilizing power relations (Angel, 2016b), reversing histories of dispossession, marginalization (Duda, 2015; Farrell, 2016) and social and environmental injustices (EDANY, 2016), and replacing monopolized fossil fuel energy systems with democratic and renewable structures (Kunze, 2014). Above all, energy democracy offers a set of visionary organizing principles that provide guidance for democratically restructuring the energy and electricity sectors through the processes of shifting from fossil fuel-based systems to renewable energy systems (Sweeney, 2014; Angel, 2016a).

Drawing from sociotechnical transition theory, the energy democracy movement may represent an example of a dealignment/re-alignment transition pathway, an ideal-type pathway for energy transition that is conceived as developing in response to serious contextual pressures (Verbong and Loorbach, 2012). This transition pathway is characterized by a significant presence of actors who have lost faith in the existing governing systems, the emergence of new guiding principles, beliefs and practices, the co-existence of multiple innovations and widespread experimentation, and a shift to more localor regional-based systems and decentralized technologies and management structures (Verbong and Loorbach, 2012). Such an agenda is intentionally incongruent with the governing systems in effect in most jurisdictions, thus deliberately lacking a goodness of fit with many current contextual pressures (Howlett and Rayner, 2013). Further, a strategy of de-alignment and re-alignment is inherently uncertain regarding the best path forward (Verbong and Loorbach, 2012), and may lead to ineffective combinations of policy instruments that fail to achieve the desired outcomes even if adopted (Kern and Howlett, 2009). In such a situation, policy tradeoffs and conflicting goals are arguably inevitable (Quitzow, 2015).

The energy democracy movement advances a vision that includes communities powered by 100 percent renewable energy (Angel, 2016b; EDANY, 2016) while asserting greater ownership and control of the energy sector in response to needs defined by communities, with the majority of energy coming from decentralized systems (Sweeney, 2012, 2014; Weinrub and Giancatarino, 2015). Energy democracy aggressively promotes energy conservation and the functioning of ecosystems (CSI, 2013; Sweeney, 2014). Ecological interdependence is respected and a project or policy is not to be pursued if the risks to humans and environment are high or poorly understood (Weinrub and Giancatarino, 2015). Energy is considered a public good or commons before a commodity (Lohmann and Hildyard, 2014; Angel, 2016b) requiring informed and conscientious communities that strive to conserve and protect all material 
resources (Weinrub and Giancatarino, 2015). Energy democracy provides a new model of economic development and key elements of a new economy. Electricity represents a multibillion-dollar industry (Farrell, 2014). Energy democracy works to keep these financial resources within the communities (Van Der Schoor et al., 2016) by establishing a clear link between local generation and local use (Hoffman and High-Pippert, 2005), potentially transforming poor and neglected communities into energy producers (CSI, 2010). Host communities, including citizens acting as prosumers (in Toffler's term; Morris, 2001) and energy citizens (Byrne and Taminiau, 2016), are to realize substantially greater economic opportunity and benefit (Farrell, 2014, 2016). Energy finance builds shared ownership and community-based resources rather than facilitating wealth accumulation (Lohmann and Hildyard, 2014; Weinrub and Giancatarino, 2015).

Energy democracy also aims to create green jobs and supports union leadership. Energy democracy seeks to protect workers' rights and generate secure and meaningful work. Achieving this objective requires that workers co-lead the energy transition and that jobs in the renewable energy sector be primarily unionized (Angel, 2016a). Central to an energy democracy agenda is a shift of power through democratic public and social ownership of the energy sector and a reversal of privatization and corporate control (Sweeney, 2014; Weinrub and Giancatarino, 2015) Energy democracy seeks to shift control over all stages of the energy sector, from production to distribution, and extending to infrastructure, finance, technology, and knowledge (Angel, 2016a) while reducing the concentration of political and economic power of the energy sector, particularly within the electricity industry (Farrell, 2016). While governance of renewable energy assets would favor public or community ownership and control (Farrell, 2014), diverse forms of ownership are needed (Farrell, 2016) that respect the political, economic and social requirements, and challenges of a specific location or community (CSI, 2013; Thompson and Bazilian, 2014). Decision-making procedures and processes would give primacy to values expressed by local communities over conventional approaches (e.g., costbenefit analysis) (Agustoni and Maretti, 2012). Mechanisms for widespread, meaningful, and democratic participation would be ensured and receive the necessary support (Weinrub and Giancatarino, 2015; EDANY, 2016). Energy policies would therefore support community-scale innovations (CSI, 2013) that serve to increase community capacity (Duda et al., 2017).

\section{States as Laboratories}

While the principles of energy democracy can be operationalized at multiple scales, in the USA the importance of states as "policy laboratories" is well recognized in the policy literature, as is the influence that state actions can have on the policy making process; this literature is rich, encompassing economic, political, and group theory frameworks (Gray, 1973; Barkenbus, 1982; Erikson et al., 1993; Andrews, 1994; Burstein and Linton, 2002; Fredriksson and Millimet, 2002; Ka Teske, 2002; Strumpf, 2002). Recognizing the critical role of state-specific innovation in policy, this research focuses on Vermont which is one of the smallest states in the country in both population and land area.
There is also a strong literature examining the impact of states on national level environmental policy and regulation (Wise and O'leary, 1997; Strumpf, 2002; Levinson, 2003; List et al., 2003; Millimet, 2003; Scheberle, 2004) and on energy policy (Barkenbus, 1982; Andrews, 1994, 2000; Ka Teske, 2002; Rabe, 2004, 2008; Wilson and Stephens, 2009). This literature encompasses both economic and political framings with which to examine the role of regulation, response to organized interests, state capacity to formulate and execute environmental and energy policy (Ringquist, 1993; Engle, 1997). Acknowledging the unique impact that state-level innovations in energy and environment can have far beyond the individual state where the innovation is occurring, case-study research reviewing specific states and specific state-level innovations has value for other states, as well as for national and international level consideration of energy transformation and environmental policy.

\section{METHODS}

To explore the challenges and opportunities of operationalizing energy democracy principles, this research focuses on empirical details of social innovations in the state of Vermont. The state of Vermont was selected as a unique and under-studied jurisdiction within the United States providing a classic example of the state as a laboratory for change and innovation. The empirical research incorporates engaged, collaborative participatory data collection involving participant observation of each of the researchers and co-authors (Yin, 2013), i.e., the researchers have drawn on their participation and experiences with energy innovations in Vermont. A compilation of multiple innovative Vermont-specific energy initiatives was selected by the authors to represent policy innovation, business innovation, and community innovation involving the government, the private sector and communities. The initiatives selected also represent examples of all three of the energy democracy priorities of resisting, reclaiming and restructuring energy systems. Diversity in scale of the different initiatives was also a goal in selecting the specific initiatives to include; the nine individual innovative initiatives range from community, town and city level to state level. Nine specific initiatives were selected and then analyzed by the research team for degree of alignment with energy democracy goals defined in a previous publication (Burke and Stephens, 2017).

\section{EXAMPLES OF OPERATIONALIZING ENERGY DEMOCRACY IN VERMONT}

This section reviews a diverse set of nine different initiatives that serve as examples of social innovations in energy in the state of Vermont. This review of these exemplar initiatives provides empirical details to explore challenges and opportunities of operationalizing energy democracy. The state of Vermont represents a unique political environment that has prioritized some key goals of energy democracy, so reviewing specific innovative energy initiatives in Vermont provides insights on operationalizing energy democracy. This section reviews several key initiatives within the Vermont context that represent 
a diversity of social innovations that operationalize energy democracy principles including initiatives to resist, reclaim, and restructure energy systems within the state. The first three of the initiatives reviewed below were selected to explicitly represent resisting, reclaiming, and restructuring of energy systems, while the latter six initiatives represent innovations that are more integrative incorporating components of all three of these energy democracy goals.

\section{Closing of Vermont Yankee-Resisting Legacy Energy Systems}

The closing of Vermont Yankee, the state's only nuclear power plant in 2014, can be viewed as an example of operationalizing energy democracy because it demonstrates powerful resistance of the legacy centralized energy system. The state of Vermont experienced widespread citizen activism that contributed to the closing Vermont Yankee. Beyond the specific impact of closing the largest central power plant in the state, the energy activism associated with the closing of Vermont Yankee has had huge influence on growing resistance to other forms of non-renewable energy including fossil fuel divestment activism and strong opposition to natural gas pipelines.

The politically supportive environment for renewables in Vermont is related to the closing of Vermont Yankee which was shut down after years of intense state-wide debate, antinuclear activism, and protests (Watts, 2012). A powerful coalition of citizens of Vermont urged lawmakers and the legislature to deny re-certification of Vermont Yankee and transition to clean, renewable wind and solar energy. In addition to the public opposition to nuclear, low electricity prices driven down by fracked gas also contributed to the decision to close Vermont Yankee. A further requirement of the closing of Vermont Yankee included providing additional funding to the Vermont Clean Energy Development Fund.

\section{Community Solar-Reclaiming Energy Systems}

The development of community solar projects in Vermont is operationalizing energy democracy by reclaiming energy systems by promoting alternative ownership models. Cooperative ownership is a key component of the energy democracy movement. Community solar projects were made possible when the Vermont legislature approved group net metering that allowed multiple customers to own a single renewable generation unit and share the output. A variety of ownership models have been promoted as representing "community solar," despite stark differences among these models with respect to the community of owners and allocation of benefits of ownership. Genuine community energy projects, such as the Boardman Hill Solar Farm, the Randolph Community Solar Farm, and White River Community Solar, take an approach that prioritizes full community ownership and careful long-term stewardship of the land.

In addition to benefitting from the policy framework described above, these projects share several innovative characteristics supporting broad community acceptance and ownership of renewable energy infrastructure in Vermont. First, these community solar projects were planned and financed by the participants. This approach encourages broader access and opens opportunities to those who might not have sufficient land or financial resources to participate independently in renewable energy generation. By not using renewable energy credits for financing, these projects can unambiguously contribute toward the state's goals for renewable energy generation. Second, each of these projects is owned and managed locally and collectively. The basic approach employs a non-profit limited liability company (LLC), using a model developed in connection with the Institute for Energy and the Environment at Vermont Law School and further facilitated by the Vermont Energy and Climate Action Network's Community Solar Toolbox. The LLC owns the technology, the tax credits, and the renewable energy credits, in addition to the electricity. This serves to change the communities' relationships to the energy system, away from simply consumers of electricity and toward relating as citizens and prosumers, while ensuring long-term participation. The commitment of these projects to local production also extends to the choice of locally-based businesses as the installers, which further extends the local economic benefits and supports employment opportunities. Finally, these community solar projects take seriously the responsibility for long-term land stewardship. The sites have been carefully chosen, the relationships with the landowner are integral to the project, and the commitment to the health of the land beyond the lifetime of the project is a core concern to the members. Together, these models of community solar serve to advance renewable energy democracy in Vermont by leveraging the transition in support of broadly-shared social, economic and environmental benefit.

\section{Ambitious State-Level Renewable Goals and Policy-Restructuring Energy Systems} The state of Vermont and its participatory democracy encouraged and supported Vermont's Comprehensive Energy Plan, which lays out an ambitious structure for state-level energy system change. The state's ambitious state-level renewable goals and policy represents operationalizing energy democracy by restructuring the future energy systems as renewable-based. This early articulation of state-level goals resulted from an intensive state-wide process of negotiation. In 1989, then Governor Madeleine Kunin called for a review of all forms of energy used in Vermont as well as a plan to modify Vermont's energy use to improve environmental quality, affordability, and renewability. This mandate resulted in the original 1991 Vermont Comprehensive Energy Plan. The Vermont Legislature further required for periodic updates to the state energy plan (30 V.S.A. \$202b) (Vermont Department Of Public Service, 1991). The Comprehensive Energy Plan of 1998 additionally included the first edition of the Vermont Greenhouse Gas Action Plan, presenting policies to reduce greenhouse gas emissions. The Comprehensive Energy Plan was then updated through an intense engaged public process in 2011 and then again in 2015-2016. The statute requires regular updating of the plan and a participatory process consisting of public hearings, forums, and 
stakeholder workshops throughout the state (Vermont Public Service Department, 2014).

In 2005, the Vermont legislative General Assembly moved to enable financing for renewable energy generation through Act 74, creating the Vermont Clean Energy Development Fund (CEDF) (Vt Department Of Public Service, 2016a). Coordinating with other state agencies and private industry, the primary goal of the CEDF is to increase renewable thermal and electrical energy generation in Vermont, supported through three objectives: (1) increase the economic development of Vermont's renewable energy sector, (2) increase the cost effectiveness/market maturity of renewable energy technologies in Vermont, and (3) decrease greenhouse gas emissions and other environmental impacts of Vermont's energy use (Vt Department Of Public Service, 2016b). The CEDF initially received funding through an agreement with Entergy Nuclear Vermont, and has also received revenue from state and federal funds and interest and principal repayments from CEDF issued loans, although the fund has yet to secure reliable funding from the state. The CEDF currently focuses on wood heating systems, particularly bulk wood pellets, that are advanced in their emissions, efficient, and use locally and sustainably harvested wood. The fund additionally supports a variety of efficiency and renewable energy programs including the Small Scale Renewable Energy Incentive Program (Vermont Dps, 2016).

The 2011 Comprehensive Energy Plan led to a two-year Total Energy Study (required by Act 170 of 2012 and modified by Act 89 of 2013), completed by the Department of Public Service in December of 2014, which identified and evaluated promising policy and technology pathways and raised questions for further analysis and consideration. A concluding claim of this study was that the state could achieve its GHG emission reduction goals and its renewable energy goals while maintaining or increasing the state's economic prosperity.

Another important policy innovation focused on net metering. Act 125 of 2012 doubled the size of solar PV systems eligible for the simple registration process to systems up to $10 \mathrm{~kW}$ from $5 \mathrm{~kW}$ and allowed customers with demand or time-of-use rates to take greater advantage of the ability to net meter (Vermont Department Of Public Service, 2013). Act 99 of 2014 raised the program capacity to $15 \%$ of utilities' peak demand, from $4 \%$. Additionally, it raised the registration process threshold for solar PV up to $15 \mathrm{~kW}$ while it lowered the solar credit by one cent per kWh for systems over this new threshold to 19 cents per kWh (State Of Vermont, 2014).

\section{Burlington: First US City to Be $100 \%$ Renewable Electricity}

The city of Burlington has recently received international fame for becoming one of the first cities to achieve $100 \%$ renewable electricity. This was achieved by the municipal utility, Burlington Electric Department, by prioritizing local renewables including a biomass power plant, the McNeil Generating Station. Also, conservation and efficiency have been prioritized in Burlington. In July 1991, the City of Burlington adopted a set of energy efficiency standards based on nationally recognized standards for new residential, commercial, and industrial construction and for substantial renovations. With regard to energy democracy, this innovation represents an effort to successfully restructure the cities energy toward renewables and resist the previous fossilfuel reliance. Given that Burlington Electric Department is a municipal utility owned and managed by the municipality, this also integrates the reclaiming component of energy democracy.

The McNeil Generating Station was constructed and connected to the New England grid in 1984. The generating station is jointly owned by Burlington Electric Department, Green Mountain Power and Vermont Public Power Supply Authority. The 40 employees are made up of a maintenance crew, equipment operators, fuel handlers, foresters, and support personnel. The plant uses 76 tons of wood chips to generate 50 MW-hours of electricity. The generator is equipped with air quality control devices that measure and limit stack emissions, generating one-tenth of the level acceptable by Vermont state regulation. The generator installed a Regenerative Selective Catalytic Reduction system and since its installation in 2008 it has cut nitrogen oxide emissions to one-third of the state's regulations. The majority of the wood that is burned comes from within 60 miles of the generator. The wood chips are from logging residue which is harvested under strict environmental standards required by the Vermont Public Service Board. The water comes from four wells around the generating station with the waste water being treated and pumped back into the Winooski River.

In September 2014, Burlington bought Winooski One Hydroelectric Facility after voters approved the purchase. The purchase reflects Burlington's mission to supply clean renewable energy to people living in the city. Winooski One is a hydroelectric generating station that generates $7.4 \mathrm{MW}$ of electric power that directed into BED's distribution system. Annually the dam generates 30 million $\mathrm{kWh}$. The dam contains a fish lift that allows the US Fish and Wildlife service to closely monitor the fish supply in the Winooski River and Lake Champlain.

\section{Leader in Utility Innovation}

Green Mountain Power (GMP), the largest utility in Vermont, developed a vision for the Energy City of the Future that focuses on the potential for energy innovation to contribute to economic development and revitalization. The focus of this effort was the City of Rutland which GMP dubbed the solar capital of New England because it has more solar generation per capita than any other city in New England. Rutland has been held up as an example for the rest of the state and the country of how renewable generation can have transformative impact on community renewal. Rutland's transition was instigated by multiple different members of the community, and GMP has been a key organization promoting renewable deployment, home efficiency retrofits, and improved efficiency (GMP, 2016)

Green Mountain Power is arguably the most innovative electric utility in the country. GMP is the only utility in the United States that has been designated a B-Corp, which is a business that is certified to meet rigorous standards of social and environmental performance, accountability, and transparency. The CEO of Green Mountain Power proudly claims that GMP 
is an energy services company, rather than an electric utility (Mckibben, 2015). Among GMP's A Rutland couple who live in a 100-year-old two-story house was approached by GMP to take part in their new energy efficient program (Mckibben, 2015). The program included retrofitting the home with cellulous insulation, solar panels, and efficient heating pumps to ultimately lower the families heating bill and make their home more comfortable. The program was issued through NeighborWorks of Western Vermont, a local non-profit housing agency that worked with the family through the entire retrofitting process. The $\$ 15,000$ cost for the program was financed by GMP and the savings realized from the homes increased efficacy covers the monthly loan payments. GMP is expanding this deep home retrofit program with a goal of another 100 homes in Rutland County with the desire for it to spread across the state (GMP, 2016). Another innovative utility program is the eVolve Panton program which is a rapid energy transformation in the small town of Panton Vermont resulting from a partnership between GMP and Efficiency Vermont. By offering residents technical assistance, financial incentives and financing toward energy transformation, Panton is set to become the first town to monitor its total energy use, know the full cost of that energy use, and measure the carbon impact. These innovations in electric utilities integrate resisting, reclaiming, and restructuring.

\section{Town Energy Committees}

The state of Vermont has a unique history and structure of local energy governance. Over one hundred communities in Vermont have active "Town Energy Committees" demonstrating a high level of public engagement on energy within the state (Rowse, 2014). In addition to providing a democratic space for local conversations about energy planning and energy innovations, these town energy committees are networked and provide input on the state-level conversation about Vermont's energy future. The focus of these committees is on both renewable energy and energy efficiency initiatives. These town energy committees are supported by the Regional Planning Commissions as well as the Vermont Energy and Climate Action Network (VECAN), an organization whose mission is to support and strengthen town energy committees throughout the state enhancing the statewide network of community-level engagement and innovation (Vecan, 2007; Vecan., 2016). Town energy committees represent a high level of local, engaged, active citizenry in Vermont.

Vermont's Act 174 of 2016 supports an approach to energy planning that aligns municipal and regional planning with statewide commitments to renewable energy development and greenhouse gas emissions. Although specific recommendations and standards are still under development by the Vermont Department of Public Service, this legislation opens the potential for greater local- and regional-level participation in renewable energy in Vermont (Vermont Dps, 2016). This act further advances previous grassroots efforts to build capacity for townlevel planning. For example, the Vermont Energy and Climate Action Network, and others have worked closely with town energy committees, hosting annual organizing and educational meetings and developing published resources to empower citizens, and local planners to engage in energy planning (Vecan, 2007; VNRC/VLCT, 2011). This local level planning and organization integrates both reclaiming and restructuring the energy systems.

\section{Innovative Energy Efficiency Policy}

Vermont energy policy has also been innovative in terms of encouraging efficiency and reducing energy consumption through creative, systematic institutional change. Among Vermont's most innovative policy creations was the creation of the nation's first state-wide energy efficiency utility-Efficiency Vermont, created in 1999 through legislation following a settlement among all Vermont electric utilities and the Vermont Department of Public Service (the City of Burlington Electric Department operates under a similar, independent agreement) (Vermont Public Service Board., 2016). An efficiency utility is a third party service provider who is charged with carrying out efficiency programs on a statewide basis. The focus on energy efficiency in Vermont began much earlier in the 1970s and 1980s with several strong advocates for energy efficiency pushing for efficiency and conservation initiatives and a 20 year electric energy plan. Administered by the Vermont Energy Investment Corporation (VEIC), an independent nonprofit energy services organization, Efficiency Vermont provides both technical assistance as well as financial incentives to support energyefficient building design, construction, renovation, equipment, lighting, and appliances. Efficiency Vermont prioritizes the reduction of the need for future power, transmission and distribution infrastructure, and greenhouse gas emissions (DSIRE, 2015). The Vermont Energy Efficiency Utility Program is funded by a volumetric energy efficiency charge on customers' bills, collected by the electric distribution utilities (Vermont Public Service Board., 2016), with additional funding provided through the Regional Greenhouse Gas Initiative and the ISO New England Forward Capacity Market (DSIRE, 2015). The idea of an electric efficiency utility was novel as it decoupled the conflicting incentives of asking electric utilities who want to sell customers electricity to promote efficiency and consume less power. The efficiency utility model has been since replicated outside of Vermont. Also Act 89 of 2013, which emerged from the work of the Thermal Efficiency Task Force, advanced informational tools such as a "clearinghouse" for thermal efficiency information and building energy labels for development. This innovation focused on energy consumption integrates resistance, reclaiming, and restructuring by reducing energy demand.

\section{The Nation's First Integrated Renewable Energy Standard}

In June of 2016 the state of Vermont became the first state to enact an integrated renewable energy standard (S. 260) which requires the distribution utilities to procure a defined percentage of their total retail electric sales from renewables. This makes utilities responsible for both supplying renewable electricity and also for supporting reductions in customers' fossil fuel use (Vermont, 2015; EIA, 2016; Vt Public Service Board, 2016). The associated Act 56 of 2015: Renewable Energy Standard (RES) establishes a requirement that electric power be: $55 \%$ renewable 
in 2017 , rising $4 \%$ every three years to $75 \%$ in 2032 (Tier 1); and $1 \%$ from distributed generators (less than $5 \mathrm{~mW}$ ) connected to Vermont's electric grid in 2017 , rising $0.6 \%$ per year, to $10 \%$ in 2032 (Tier 2). The RES is unique in that it also requires electric utilities to reduce fossil fuel use by their customers by an amount equivalent to $2 \%$ of retail electric sales in 2017 , rising two-thirds of a percent per year to $12 \%$ by 2032 (Tier 3 ). A utility can meet this requirement through energy transformation projects that result in net reduction of fossil fuel consumption by the utility's customers or through additional distributed renewable energy generation. Examples include electric vehicles and related infrastructure; building weatherization; and increased use of biofuels. Act 56 in its passing, also addressed the siting of electric generators by establishing the Solar Siting Task Force, which has been tasked to study the design, siting, and regulatory review of solar facilities.

An additional recent policy innovation aligned with the energy democracy goal of resisting the fossil fuel regime is the carbon pollution tax. A strong current coalition advocating for a state-wide carbon pollution tax has recently broadened to include multiple different proposals involving different priorities for how to use the additional tax revenue (Energy Independent Vermont, 2017). The current Vermont Governor is not in favor of a carbon pollution tax so this has become quite controversial representing growing tensions within the state.

\section{Networks and Organizational Innovations}

Vermont is home to a number of non-profit and forprofit energy policy and programmatic organizations that have had a great impact on the state's innovative energy policy. These organizations innovations have contributed to a highly networked state energy landscape. For example, the Regulatory Assistance Project (RAP), founded in the 1980s, provides consulting services to public entities around the world and has grown into an internationally known and trusted voice to support energy efficiency and renewable energy policy and legislation. The establishment of the Energy Action Network (EAN) in 2009 is another innovation that facilitates communication among key actors and organizations throughout the state. Vermont's Energy Action Network (EAN) is a unique statewide organization whose principal purpose is to use a cross-sectoral network approach to advance Vermont's transition to a sustainable energy future (Figure 1). EAN is a diverse group of nonprofits, businesses, public agencies, utilities and educators, and other high-level stakeholders working collectively to meet $90 \%$ of our 2050 energy needs through efficiency and renewables across four key leverage points: capital mobilization, technology innovation, public engagement and regulatory reform. At EAN's 2015 annual meeting, the organizers designated an entire opening session to encourage members to reflect on the social value of a network including a focus on relationships, communication, and collective impact. This sophisticated and self-reflective session highlighted the impact of working for change through a cross-sector coalition rather than through a single organization (Kania and Kramer, 2013). The state has also made key moves toward integrated planning of transmission and distribution to address reliability concerns. Additionally, the state has adopted policies for rate decoupling and group and virtual net metering, and has implemented a standard offer program to encourage small-scale renewable generation (Farrell, 2014). These networks are simultaneously involved in resisting, reclaiming and restructuring Vermont's energy systems.

\section{OPERATIONALIZING ENERGY DEMOCRACY IN VERMONT}

Each of the examples of energy innovations described in section Examples of Operationalizing Energy Democracy in Vermont represent intentional democratic attempts to resist, reclaim, and restructure the state's energy systems toward a renewable energy future. While the first three initiatives were selected to explicitly demonstrate resistance, reclaiming, and restructuring, the additional initiatives are more integrative incorporating components of all three (arguably focusing more on reclaiming and restructuring than resisting).

Through a combination of policy, institutional, and cultural innovations, Vermonters are actively involved in visioning and advancing a different energy future. Vermont has been identified as a state with a unique energy landscape worth keeping track of as energy democracy goals are advanced (Farrell, 2014). This review of several specific energy innovations in Vermont provides insights on operationalizing energy democracy.

One key aspect of considering the opportunities for energy democracy operationalization in Vermont is the state's small size. Through the participatory-observation methods integrated into this research involving each of the co-authors direct engagement, it becomes clear that the small scale of the state of Vermont results in interconnecting networks of stakeholders who know each other. These interconnections among stakeholders across the state and the comparatively short distances that stakeholders have to travel to convene results in broad participation across the state. This participation, in turn, seems to lead to multiple frequent mechanisms for communication among a diversity of stakeholders. The sharing of information appears to be easier than in other places, and alignment of common goals appears to be more readily achievable because of multiple informal connections among key actors. Vermont seems to foster a culture of community, collaboration, state pride, and public engagement, so many residents of Vermont are active and engaged in their communities. This high level of engagement and the small size results in a sense of state-wide collaboration toward a renewable energy transition and fosters an application of democratic processes to energy planning.

Other factors that are unique to Vermont when considering operationalizing energy democracy ideals are the minimal fossil fuel interests in the state. Unlike many other jurisdictions, Vermont has no fossil fuel resources, and Vermont is the only state in the nation with no large fossil fuel power plants, so the liquid fossil fuel dealers are the primary fossil fuel interests in the state. Vermont has over 17,700 jobs in the clean energy sector, which accounts for almost $6 \%$ of the workforce, up from $4.8 \%$ 


\section{EAN System Mapping}

\section{Leverage Points}

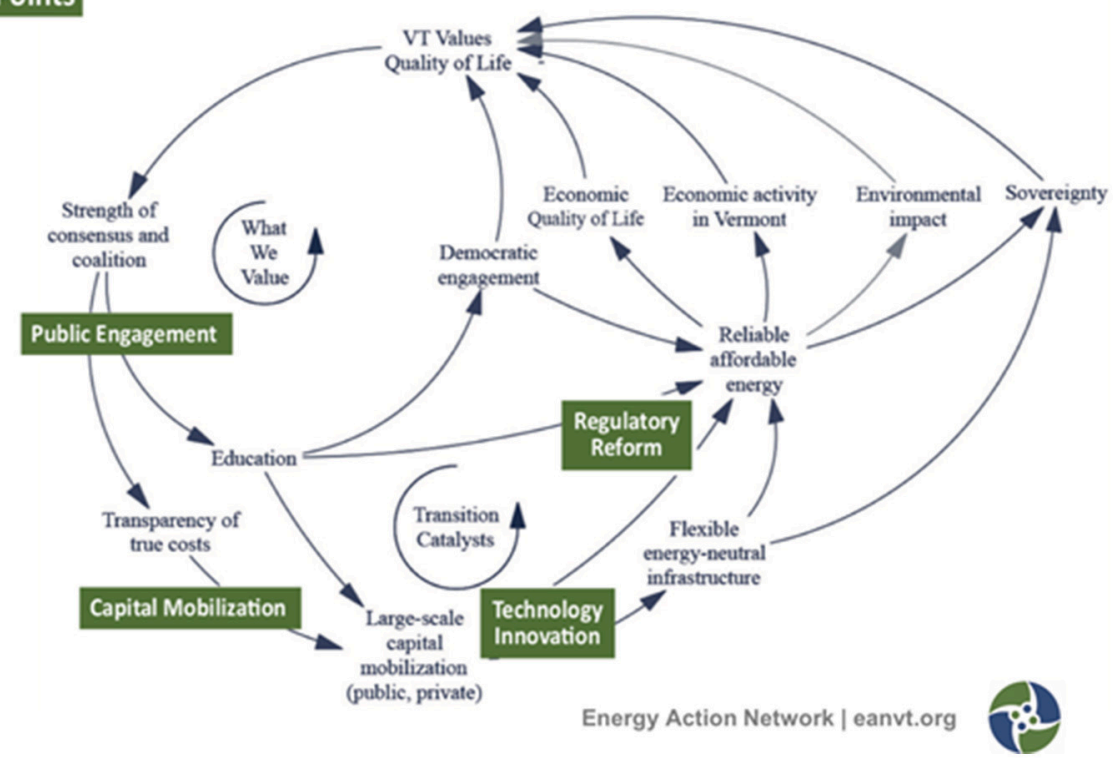

FIGURE 1 | A social system network map of the Vermont energy innovation system created by the Vermont Energy Action Network (EAN, 2016). Reproduced with permission of the Vermont Energy Action Network.

in 2015, and 4.3\% in 2014 (Clean Energy 2016 Industry Report, prepared for the Vermont Clean Energy Development Fund). In addition, national rankings regularly identify Vermont as one of the top ten spots leading per capita renewable energy jobs, particularly those related to solar and efficiency (Clean Edge, 2016).

In addition to these positive opportunities for operationalizing energy democracy principles in Vermont, there are also multiple challenges. In particular, there is limited community ownership of renewable energy projects. This lack of community ownership has resulted in widespread tension and opposition to many of the proposed renewable energy projects throughout the state. Controversy surrounding siting of wind and solar installations has been fierce in many parts of the state, and has similarities to resistance to renewables in many parts of the country (Peterson et al., 2015). Much of this opposition is related to local communities not having ownership and therefore not sharing in potential future benefits of renewable installations. This opposition has led to some scaling back of policy incentives and a slow-down of deployment of both solar and wind. Opposition to transmission lines, including transmission from hydropower from Quebec, has also been strong in some communities (Watts and Kaza, 2013). New state rules approved in fall 2017 limit the sound from wind power to such a degree that no large wind power projects will be built while this rule is in place.

Among the many challenges of operationalizing energy democracy goals that emerge is the prominent role of the private sector. The renewable energy industry in Vermont is strong and politically involved in advancing ambitious renewable energy policies. The influence of the private sector is at odds with some of the community-oriented goals of the energy democracy agenda, and the sector generally lacks a strong union presence. The limited examples of alternative ownership models in Vermont is clear challenge of operationalizing energy democracy, and a place where Vermont has strong potential to continue to innovate.

While the citizen opposition to Vermont Yankee and some recent renewable installations demonstrates the power of resistance in Vermont, many of the renewable energy activists are quite separate and lacking connections to those working to resist fossil fuels. There seems to be only a few organizations that are simultaneously resisting non-renewables while also advocating for reclaiming and restructuring toward renewables.

An additional challenge of operationalizing energy democracy in Vermont relates to the limited attention to the most vulnerable individuals and households and injustices within the energy system. A unique consideration in Vermont is the limited racial diversity of the state. The larger energy democracy movement has emerged most strongly in urban contexts where socioeconomic and racial disparities are critical social justice issues that are being connected to energy system change, but the comparatively racially homogeneous population in Vermont has meant that racial injustices are not prominent. Socioeconomic disparities and inequalities are widely acknowledged in Vermont, but only some energy innovations within the state are prioritizing the potential for the renewable energy transition to redistribute jobs and economic power. As a result of these and other challenges, progress lags behind the state's goals. 


\section{CONCLUSIONS}

As a transformation toward more renewable-based energy systems accelerates, the principles of energy democracy provides guidance on redistributing economic and political power during the transition. But operationalizing those principles is both challenging and ripe with opportunity. The energy democracy movement provides a framework to resist, reclaim, and restructure energy systems (Sweeney, 2012, 2014) in the transition away from fossil fuels. Within the political context of the United States, the small state of Vermont provides valuable insights on challenges of operationalizing these energy democracy goals. One noticeable challenge (and opportunity) is the apparent inability of organizations and initiatives to simultaneously embrace working toward resisting, reclaiming and restructuring. Many individuals and organizations in Vermont are focusing on advancing renewable energy rather than paying attention to how to resist the continued fossil fuel reliance. A largely unrecognized challenge is how to reduce the entrenched fossil fuel dependence throughout the state-much of which is associated with transportation and heating. While resistance to nuclear at Vermont Yankee was strong throughout the state, a similar resistance to fossil fuels has not emerged. This lack of resistance is due in part to the lack of a large tangible fossil fuel power plants and the distributed reliance among almost everyone in the state for both transportation and heating. Carbon pollution tax proposals are the primary fossil fuel resistance efforts in the state of Vermont, and the strong controversy surrounding those demonstrate the more general challenge of resisting the dominant and entrenched component of the energy system.

The limited focus on distributed ownership and labor organization in the energy sector in the Vermont context represents a fruitful area for future innovations in Vermont and beyond. Additional comparative research on the motivation, structure and evolution of community energy initiatives in Vermont would be a valuable contribution to the growing community energy research (Macarthur, 2016; Hoicka and Macarthur, 2018).

Another interesting aspect of Vermont's ambitious energy policy is the focus on $90 \%$ renewable rather than $100 \%$ (Jacobson et al., 2015; Diesendorf and Elliston, 2018). While the energy democracy movement explicitly aims for $100 \%$ renewable, Vermont's goal of $90 \%$ by 2030 represents a practical

\section{REFERENCES}

Agustoni, A., and Maretti, M. (2012). Energy and social change: an introduction. Int. Rev. Soc. 22, 391-404. doi: 10.1080/03906701.2012.7 30820

Andrews, C. J. (1994). Electricity and federalism, understanding regional diversity. Energy Policy 22, 629-638. doi: 10.1016/0301-4215(94)90 081-7

Andrews, C. J. (2000). Diffusion pathways for electricity deregulation. Publius 30, 17-34. doi: 10.1093/oxfordjournals.pubjof.a030093

Angel, J. (2016a). Strategies of Energy Democracy. Brussels: Rosa-LuxemburgStiftung. acknowledgment of the challenge of reducing that last $10 \%$ of fossil fuel reliance (Heinberg and Fridley, 2016).

While a rich literature has focused on social acceptance of renewable energy deployment, this empirical review of several energy innovations in Vermont suggests that more attention should be paid to innovations in participation, ownership and financing. Recognizing that local community ownership is critical to distributing the economic and political power associated with renewable energy, Vermont demonstrates how controversy can emerge despite a culture of collaboration and experimentation, limiting the transition.

As the steady and growing concerns with climate change and fossil fuel dependence at the national and international levels provide the broader backdrop at the macro-level for the energy democracy movement, the combined efforts of the state of Vermont, including the Vermont legislature, several supportive gubernatorial administrations, and pressure and involvement of the Vermont citizenry, create a unique place where energy innovations are thriving. Despite this positive potential and a highly participatory culture of democracy, the operationalization of energy democracy principles, particularly distributed ownership, remains minimal and contested, limiting the transition.

\section{AUTHOR CONTRIBUTIONS}

JCS coordinated this collaborative effort and contributed to data collection and writing the paper. MJB researched specific innovations and contributed to writing the paper. BG and EJ researched specific innovations. RW provided insights on the specific innovations and contributed to writing the paper.

\section{FUNDING}

This research was supported by the Blittersdorf Professorship of Sustainability Science and Policy at the University of Vermont.

\section{ACKNOWLEDGMENTS}

We would like to thank the extended Vermont renewable energy community. We also acknowledge with particular appreciation the renewable energy stakeholders who were involved in this research by providing their valuable perspectives through conversations and reviewing of drafts. an International Workshop (Workshop report). Amsterdam: Transnational Institute.

Araujo, K. (2014). The emerging field of energy transitions: progress, challenges and opportunities. Energy Res. Soc. Sci. 1, 112-121. doi: $10.1016 /$ j.erss.2014.03.002

Arent, D., Arndt, C., Miller, M., Tarp, F., and Zinaman, O. (2017). The Political Economy of Clean Energy Transitions. New York, NY: Oxford University Press.

Barkenbus, J. N. (1982). Federal energy policy paradigms and state energy roles. Public Adm. Rev. 42, 410-418. doi: 10.2307/975643

Boyer, D. (2014). Energopower: an introduction. Anthropol. Q. 87, 309-333. doi: 10.1353 /anq.2014.0020 
Brown, L., Larsen, J., Roney, J. M., and Adams, E. E. (2015). The Great Transition: Shifting From Fossil Fuels to Solar and Wind Energy. New York, NY: Earth Policy Institute, W.W. Norton.

Burke, M., and Stephens, J. C. (2017). Energy democracy: goals and policy instruments for sociotechnical transition. Energy Res. Soc. Sci. 33, 35-48. doi: 10.1016/j.erss.2017.09.024

Burke, M. J. (2018). Shared yet contested: Energy democracy counter-narratives. Front. Commun. 3:22. doi: 10.3389/fcomm.2018.00022

Burke, M. J., and Stephens, J. C. (2018). Political power and renewable energy futures: a critical review. Energy Res. Soc. Sci. 35, 78-93. doi: $10.1016 /$ j.erss.2017.10.018

Burstein, P., and Linton, A. (2002). The impact of political parties, interest groups, and social movement organizations on public policy: some recent evidence and theoretical concerns. Soc. Forces 81, 380-408. doi: 10.1353/sof. 2003.0004

Busch, H., and Mccormick, K. (2014). Local power: exploring the motivations of mayors and key success factors for local municipalities to go $100 \%$ renewable energy. Energy Sustain. Soc. 4:5. doi: 10.1186/21920567-4-5

Byrne, J., and Taminiau, J. (2016). A review of sustainable energy utility and energy service utility concepts and applications: realizing ecological and social sustainability with a community utility: review of SEU and energy service utility concepts and applications. Wiley Interdiscip. Rev. Energy Environ. 5, 136-154. doi: 10.1002/wene.171

Cherp, A., Vinichenko, V., Jewell, J., Brutschin, E., and Sovacool, B. (2018). Integrating techno-economic, socio-technical and political perspectives on national energy transitions: a meta-theoretical framework. Energy Res. Soc. Sci. 37, 175-190. doi: 10.1016/j.erss.2017.09.015

Clean Edge (2016). Clean Edge: Indexing the Clean Energy Economy. U.S. Clean Tech Leadership Index.

Clegg, J. M. (2014). The Winds of Change: The Political Ecology of Renewable Energy Transition in Vermont. Master of Science, The New Jersey Institute of Technology's Electronic Theses and Dissertations Project.

CSI (2010). Energy Democracy: Community-Scale Green Energy Solutions. New York, NY: Center for Social Inclusion.

CSI (2013). Energy Democracy: Community-Led Solutions - Three Case Studies. New York, NY: Center for Social Inclusion.

Diesendorf, M., and Elliston, B. (2018). The feasibility of $100 \%$ renewable electricity systems: a response to critics. Renew. Sustain. Energy Rev. 93, 318-330. doi: 10.1016/j.rser.2018.05.042

DSIRE (2015). Efficiency Vermont. Available online at: http://programs.dsireusa. org/system/program/detail/2019

Duda, J. (2015). Energy, Democracy, Community. Available online at: https:// medium.com/@JohnDuda/energy-democracy-community-320660711cf4\#. jtxijr47s (Accessed June 27, 2016).

Duda, J., Hanna, T., and Burke, M. (2017). Building Community Capacity for Energy Democracy: A Deck of Strategies. The Next System Project. Available online at: https://thenextsystem.org/learn/collections/building-communitycapacity-energy-democracy-deck-strategies

EAN (2016). Community Energy Dashboard and User Guide. Available online at: http://www.vtenergydashboard.org/about: Energy Action Network.

EDANY (2016). New York State Energy Democracy Alliance - Formation, Organization, and Moving our Agenda: A Report From our First 18 Months. New York, NY: Energy Democracy Alliance.

EIA (2016). Energy Production Estimates. Available online at: http://www.eia.gov/ state/seds/sep_prod/pdf/P5A.pdf

Energy Independent Vermont (2017). Carbon Pollution Tax Bill Overview. Available online at: http://www.energyindependentvt.org/wp-content/uploads/ 2015/03/2015-03-Pollution-Tax-Bill-Overview.pdf

Engle, K. H. (1997). State environmental standard setting: is there a "Race" and is it "to the bottom"? Hastings Law J. 48, 271-376.

Erikson, R. S., Wright, G. C., and Mciver, J. P. (1993). Statehouse Democracy: Public Opinion and the American States.

Farrell, J. (2014). Beyond Utility 2.0 to Energy Democracy. Institute for Local Self-Reliance.

Farrell, J. (2016). Beyond Sharing: How Communities Can Take Ownership of Renewable Power (Energy Democracy Initiative). Institute for Local SelfReliance.
Fredriksson, P. G., and Millimet, D. L. (2002). Strategic interaction and the determination of environmental policy across US states. J. Urban Econ. 51, 101-122. doi: 10.1006/juec.2001.2239

Geels, F. W., Sovacool, B. K., Schwanen, T., and Sorrell, S. (2017). Sociotechnical transitions for deep decarbonization. Science 357, 1242-1244. doi: 10.1126/science.aao3760

GMP (2016). The Solar Capital of New England. Available online at: http://www. greenmountainpower.com/innovative/solar_capital/the-solar-capital-of-newengland/

Gray, V. (1973). Innovation in the States: a diffusion study. Am. Polit. Sci. Rev. 67, 1174-1185. doi: 10.2307/1956539

Healy, N., and Barry, J. (2017). Politicizing energy justice and energy system transitions: Fossil fuel divestment and a just transition. Energy Policy 108(Supp C), 451-459. doi: 10.1016/j.enpol.2017.06.014

Heinberg, R., and Fridley, D. (2016). Our Renewable Future: Laying the Path for One Hundred Percent Clean Energy. Island Press.

Hoffman, S. M., and High-Pippert, A. (2005). Community energy: a social architecture for an alternative energy future. Bull. Sci. Technol. Soc. 25, 387-401. doi: $10.1177 / 0270467605278880$

Hoicka, C. E., and Macarthur, J. L. (2018). From tip to toes: Mapping community energy models in Canada and New Zealand. Energy Policy 121, 162-174. doi: 10.1016/j.enpol.2018.06.002

Howlett, M., and Rayner, J. (2013). Patching vs packaging in policy formulation assessing policy portfolio design. Politics Govern. 1, 170-182. doi: $10.17645 /$ pag.v1i2.95

IRENA (2017). REthinking Energy 2017: Accelerating the Global Energy Transformation. Abu Dhabi: International Renewable Energy Agency.

Islar, M., and Busch, H. (2016). "We are not in this to save the polar bears!" - the link between community renewable energy development and ecological citizenship. Innov. Eur. J. Soc. Sci. Res. 29, 303-319. doi: 10.1080/13511610.2016.1188684

Jacobson, M. Z., and Delucchi, M. A. (2011). Providing all global energy with wind, water, and solar power, Part I: technologies, energy resources, quantities and areas of infrastructure, and materials. Energy Policy 39, 1154-1169. doi: 10.1016/j.enpol.2010.11.040

Jacobson, M. Z., Delucchi, M. A., Bazouin, G., Bauer, Z. A. F., Heavey, C. C., Fisher, E., et al. (2015). 100\% clean and renewable wind, water, and sunlight (WWS) all-sector energy roadmaps for the 50 United States. Energy Environ. Sci. 8, 2093-2117. doi: 10.1039/C5EE01283J

$\mathrm{Ka}$ and Teske (2002). Ideology and professionalism, electricity regulation and deregulation over time in the American States. Am. Polit. Res. 30, 323-343. doi: 10.1177/1532673X02030003006

Kania, J., and Kramer, M. (2013). Embracing Emergence: How Collective Impact Addresses Complexity. Stanford Social Innovation Review.

Kern, F., and Howlett, M. (2009). Implementing transition management as policy reforms: a case study of the Dutch energy sector. Policy Sci. 42:391. doi: 10.1007/s11077-009-9099-x

Kunze, C. (2014). What is Energy Democracy?Available online at: http://energiedemokratie.de/what-is-energy-democracy/ (Accessed June 27, 2016).

Levine, S. (2016). Clean Energy Powerhouse. VT Digger.

Levinson, A. (2003). Environmental regulatory competition: a status report and some new evidence. Natl. Tax J. 56, 91-106. doi: 10.17310/ntj. 2003.1.06

List, J. A., Millimet, D. L., and Al, E. (2003). Effects of environmental regulations on manufacturing plant births: evidence from a propensity score matching estimator. Rev. Econ. Stat. 85, 944-952. doi: 10.1162/003465303772 815844

Lohmann, L., and Hildyard, N. (2014). Energy, Work and Finance. Dorset: Corner House.

Maatsch, H. W. (2014). Energiewende: energy transition in Germany. The Guardian.

Macarthur, J. L. (2016). Empowering Electricity? Co-operatives, Sustainability and Power Sector Reform in Canada. BC Press.

Markard, J., Raven, R., and Truffer, B. (2012). Sustainability transitions: an emerging field of research and its prospects. Res. Policy 41, 955-967. doi: 10.1016/j.respol.2012.02.013

Mckibben, B. (2015). Power to the people: why the rise of green energy makes utility companies nervous. The New Yorker. 
Meadowcroft, J. (2009). What about the politics? Sustainable development, transition management, and long term energy transitions. Policy Sci. 42, 323-340. doi: 10.1007/s11077-009-9097-z

Miller, C. A., Iles, A., and Jones, C. F. (2013). The social dimensions of energy transitions. Sci. Cult. 22, 135-148. doi: 10.1080/09505431.2013.786989

Millimet, D. L. (2003). Assessing the empirical impact of environmental federalism. J. Reg. Sci. 43, 711-733. doi: 10.1111/j.0022-4146.2003.00317.x

Morris, C., and Jungjohann, A. (2016). Energy Democracy: Germany's Energiewende to Renewables. Palgrave Macmillan.

Morris, D. (2001). Seeing the Light. Institute for Local Self-Reliance. Available online at: https://www.pharosproject.net/uploads/files/sources/1/1349813941.pdf

Parker, S., and Huessy, F. (2014). "The utility of the future: building customer equity in the next generation," in American Council for an Energy-Efficient Economy 2014 Conference.

Peterson, T. R., Stephens, J. C., and Wilson, E. J. (2015). Public perception of and engagement with emerging low-carbon energy technologies: a literature review. MRS Energy Sustain. 2, 1-14. doi: 10.1557/mre.2015.12

Princen, T., Manno, J. P., and Martin, P. L. (2015). Ending the Fossil Fuel Era. Cambridge, MA: The MIT Press.

Quitzow, R. (2015). Assessing policy strategies for the promotion of environmental technologies: a review of India's National Solar Mission. Res. Policy 44, 233-243. doi: 10.1016/j.respol.2014.09.003

Rabe, B. G. (2004). Statehouse and Greenhouse. The Emerging Politics of American Climate Change Policy. Washington, DC: Brookings Institution.

Rabe, B. G. (2008). States on steroids: the intergovernmental odyssey of American climate policy. Rev. Policy Res. 25, 105-128. doi: $10.1111 / j .1541-1338.2007 .00314 . x$

Reed, E. (2015), September 12). How Vermont became a clean-power powerhouse. Christian Science Monitor.

REN21 (2017). Renewables Global Futures Report: Great Debates Towards 100\% Renewable Energy. Paris: REN21 Secretariat.

Ringquist, E. J. (1993). Environmental Protection at the State Level: Politics and Progress in Controlling Pollution. M.E. Sharpe.

Rowse, T. (2014). Local Energy Governance in Vermont: An Analysis of Energy System Transition Strategies and Actor Capacity. University of Vermont.

Scheberle, D. (2004). Federalism and Environmental Policy: Trust and the Politics of Implementation. Georgetown University Press.

Smith, A., and Raven, R. (2012). What is protective space? Reconsidering niches in transitions to sustainability. Res. Policy 41, 1025-1036. doi: 10.1016/j.respol.2011.12.012

State Of Vermont (2014). No.99 An Act Relating to Self-Generation and NetMetering. Available online at: http://www.leg.state.vt.us/DOCS/2014/ACTS/ ACT099.PDF

Stephens, J. C., Wilson, E. J., and Peterson, T. R. (2015). Smart Grid (R)Evolution: Electric Power Struggles. Cambridge University Press.

Stirling, A. (2014). Transforming power: social science and the politics of energy choices. Energy Res. Soc. Sci. 1, 83-95. doi: 10.1016/j.erss.2014.02.001

Stokes, L. C., and Breetz, H. L. (2018). Politics in the U.S. energy transition: Case studies of solar, wind, biofuels and electric vehicles policy. Energy Policy 113, 76-86. doi: 10.1016/j.enpol.2017.10.057

Strumpf, K. S. (2002). Does governmental decentralization increase policy innovation? J. Public Econ. Theory 4, 207-241. doi: 10.1111/1467-9779.00096

Sweeney, S. (2012). Resist, Reclaim, Restructure: Unions and the Struggle for Energy Democracy. Trade Unions for Energy Democracy. Discussion Document Prepared for the Energy Emergency: Developing Trade Union Strategies for a Global Transition Trade Union Roundtable. New York, NY. Available online at: www.unionsforenergydemocracy.org (Accessed October 10-12, 2012).

Sweeney, S. (2014). Working Toward Energy Democracy. State of the World 2014. Springer.

Szulecki, K. (2018). Conceptualizing energy democracy. Environ. Polit. 27, 21-41. doi: $10.1080 / 09644016.2017 .1387294$

Thompson, G., and Bazilian, M. (2014). Democratization, energy poverty, and the pursuit of symmetry. Global Policy 5, 127-131. doi: 10.1111/1758-5899.12103

Van Der Schoor, T., Lente, H., Van, S., B., and Peine, A. (2016). Challenging obduracy: how local communities transform the energy system. Energy Res. Soc. Sci. 13, 94-105. doi: 10.1016/j.erss.2015.12.009
Van Veelen, B., and Van Der Horst, D. (2018). What is energy democracy? Connecting social science energy research and political theory. Energy Res. Soc. Sci. 46, 19-28. doi: 10.1016/j.erss.2018.06.010

Vecan (2007). Town Energy and Climate Action Guide.

Vecan. (2016). Vermont Energy and Climate Action Network: Energinzing Vermont Communities. Available online at: http://www.vecan.net/

Verbong, G., and Loorbach, D. (2012). Governing the Energy Transition: Reality, Illusion or Necessity? New York, NY: Routledge.

Vermont Department Of Public Service (2013). Evaluation of Net Metering in Vermont, Pursuant to Act 125 of 2012. Available online at: http://www.leg.state. vt.us/reports/2013externalreports/285580.pdf

Vermont Department Of Public Service (1991). Vermont Comprehensive Energy Plan. DPS.

Vermont Dps (2016). Act 174 Recommendations and Determination Standards. State of Vermont Department of Public Service. Available online at: http://publicservice.vermont.gov/content/act-174-recommendations-anddetermination-standards

Vermont Public Service Department (2014). Total Energy Study. Final Report on a Total Energy Approach to Meeting the State’s Greenhouse Gas and Renewable Energy Goals.

Vermont Public Service Department (2016). Comprehensive Energy Plan.

Vermont Public Service Board. (2016). Energy Efficiency Utility Creation and Structure. Available online at: https://puc.vermont.gov/energy-efficiencyutility-program

Vermont, S. O. (2015). Act No 56. An Act Relating to Establishing a Renewable Energy Standard. Available online at: http://legislature.vermont.gov/assets/ Documents/2016/Docs/ACTS/ACT056/ACT056\%20As\%20Enacted.pdf

VNRC/VLCT (2011). Energy Planning and Implementation Guidebook for Vermont Communities. Available online at: http://www.vecan.net/resources/ publications/: Vermont Natural Resources Council (VNRC) and Vermont League of Cities and Towns (VLCT).

Vt Department Of Public Service (2016a). Clean Energy Development Fund. Montpelier, VT: Vermont Department of Public Service.

Vt Department Of Public Service (2016b). Vermont Clean Energy Development Fund Fiscal Year 2017 Annual Program Plan and Allocations. Montpelier, VT: Department of Public Service.

Vt Public Service Board (2016). Order Implementing the Renewable Energy Standard. Montepelier, VT: Vermont Public Service Board.

Watts, R. A. (2012). Public Meltdown: The Story of Vermont Yankee Nuclear Power Plant. White River Press.

Watts, R. A., and Kaza, S. (2013). Planning for power: frame production in an environmental conflict over the siting of a high-voltage transmission line. J. Environ. Stud. Sci. 3, 247-258. doi: 10.1007/s13412-0130134-z

Weinrub, A., and Giancatarino, A. (2015). Toward a Climate Justice Energy Platform: Democratizing our Energy Future. Local Clean Energy Alliance/Center for Social Inclusion.

Wilson, E. J., and Stephens, J. C. (2009). Wind in a carbon-managed world: states, resources, policy and discourse. Environ. Sci. Technol. 43, 9063-9070. doi: $10.1021 / \mathrm{es} 900802 \mathrm{~s}$

Wise, C., and O'leary, R. (1997). Intergovernmental relations and federalism in Environmental Management and Policy: the role of the courts. Public Adm. Rev. 57, 150-159.

Yin, R. (2013). Case Study Research Design and Methods. Sage Publications.

Conflict of Interest Statement: The authors declare that the research was conducted in the absence of any commercial or financial relationships that could be construed as a potential conflict of interest.

Copyright $\odot 2018$ Stephens, Burke, Gibian, Jordi and Watts. This is an open-access article distributed under the terms of the Creative Commons Attribution License (CC $B Y)$. The use, distribution or reproduction in other forums is permitted, provided the original author(s) and the copyright owner(s) are credited and that the original publication in this journal is cited, in accordance with accepted academic practice. No use, distribution or reproduction is permitted which does not comply with these terms. 